\title{
CORRESPONDENCE
}

\section{Alice Economics}

SiR,-We feel that you have failed to understand the issues involved in continued economic growth (Nature, 234, 2 ; 1971). It is undeniable that pollution has accompanied economic growth. It may be that economic resources are required to stem the effects on the environment, but before this can be brought about a whole new political atmosphere is needed: our economic efforts must be redirected. Much of the economic effort in modern industrialized communities, such as the EEC, is invested in the production of non-essential consumer goods, aerospace and defence technologies, and other areas where raw materials are consumed almost unthinkingly and where attendant pollution problems are solved, if at all, only as an after-thought.

The industry of the future should be one in which a much greater proportion of the materials used will already have been recycled many times. It should be manufacturing items which are more directly applicable to the world's problems, such as medical goods, birth control devices, agricultural materials, and housing materials. The need for these goods is mainly in poorer countries. The required revolution in the foreign aid and internal economic policies of the rich countries will not be achieved without a radical change in political atmosphere, and we share Professor Scorer's disappointment that no mention of these points was made in the EEC debates.

It is indeed no accident that the richest nation is the most worried about pollution, since it has considerably more than the rest of us, as a result of greater economic advance, and is feeling the effects earlier than most. In pollution terms, and in terms of per capita use of natural resources, one American has a far greater impact than, for example, one Indian. Also, many American citizens are aware of the continuing failure of their political leadership to deal with these problems, and do not share your blind faith that all will turn out right in the end.

What you ignore is that we live in a world which has only a limited quantity of raw materials and can only support a finite population. The plain fact is that the world could not support even its present population if everyone shared the American standard of living: if we wish everyone to be decently fed and housed, somebody has to be prepared to give. That includes us.

Yours faithfully,

\section{J. Bolton \\ J. E. CORDWELl}

154 Redland Road,

Bristol BS6 6TD

\section{Alice Economics}

SIR,-I find the editorial attitude expressed in Professor Scorer's letter to The Times distressing; and, worse, bigoted. If he is irresponsible in his "environmentalist" attitudes, so indeed are you with your "growth is a prerequisite to improvement" attitude. Do you have a connexion with economists? It appears to me that only they of our ideological dinosaurs continue to put all their eggs in the long since worn out basket of required economic growth via an expanding population. Surely economic growth can also be achieved with a static or even a decreasing population?

Overall there is perhaps only one obvious fact, one which you choose to ignore, and which is the basis of Professor Scorer's letter. This is the need for a fundamental change of some sort. To a mathematician, or indeed any logically inclined person, the exponential curve of population growth can have only one answer, and that is change. The change may be controlled or cataclysmic, but change there will be.

Your comparison of our small and already overcrowded island with the USA (some four times the population in around forty times the area) is ridiculous. That country, with presentday technology, is already capable of feeding its estimated population for the year 2000 and beyond, while our population has already outgrown our own food supply. Indeed, even India, with around eight times the population in twelve times the area, is better placed; when the pressures arise, we shall be among the first to experience them.

Your dismissal of the pollution problem on the grounds of lack of specificity is irresponsible. More worrying is your lack of awareness that the decrease in fish landings to which you refer is itself a form of pollution. Pollution by taking needs to be considered with pollution by dumping.
The Kansas dust-bowls were not produced by the dumping of dust.

Your patronizing attitude to our poorer neighbours must irk them in the extreme. Must they continually rely on aid based on a fraction of our growth? Again a mathematically (and historically) unacceptable model in the long term.

May I say finally that I already find the pressures of today's society bearable only with difficulty, and that I take Professor Scorer's ideas seriously enough to wonder if I wish to take part in your rich and sterile utopia with its increasingly (and necessarily) controlled overpopulation. Yours faithfully,

\section{A. Ellis}

Westfield College,

University of London,

London NW3

\section{Ethics for Authors}

SIR,-As editors of a monograph series published by a well known university press, we have each had recently the following experience. A competent scientist asks us to consider publishing a book which he has on hand. We reply showing interest, and negotiations begin, involving the assessment of a synopsis and sample chapters, a check on the existing literature, and advice to the press to publish. Improvements of style and content are suggested to the author, and a formal contract is prepared. This is a lengthy procedure and may take many months. We are then told that the finished book has been accepted by another publisher, with whom, in fact, the author was simultaneously negotiating.

In the selling of a house such conduct is usually regarded as dishonourable, if not quite actionable. In the jungle of commercial publishing one must, no doubt, be prepared for such dishonesty. But in the production of specialized scholarly works this is unethical behaviour, not at all in the interests of authors themselves.

It is true that we are paid as editors in proportion to the success of the books that we get into print. Some unscrupulous editors and publishers make a quick profit by accepting every manuscript, without question or revision and wax rich on high-priced sales to libraries. But most scholarly editors do not do this sort of job solely for monetary 